\title{
Complete plastome sequences of Equisetum arvense and Isoetes flaccida: implications for phylogeny and plastid genome evolution of early land plant lineages
}

Kenneth G Karol ${ }^{1 *}$, Kathiravetpillai Arumuganathan ${ }^{2}$, Jeffrey L Boore ${ }^{3,4}$, Aaron M Duffy ${ }^{5}$, Karin DE Everett ${ }^{6}$, John D Hall', S Kellon Hansen ${ }^{5}$, Jennifer V Kuehl', Dina F Mandoli, ${ }^{6,8}$, Brent D Mishler ${ }^{9}$, Richard G Olmstead ${ }^{6}$, Karen S Renzaglia ${ }^{10}$, Paul G Wolf

\begin{abstract}
Background: Despite considerable progress in our understanding of land plant phylogeny, several nodes in the green tree of life remain poorly resolved. Furthermore, the bulk of currently available data come from only a subset of major land plant clades. Here we examine early land plant evolution using complete plastome sequences including two previously unexamined and phylogenetically critical lineages. To better understand the evolution of land plants and their plastomes, we examined aligned nucleotide sequences, indels, gene and nucleotide composition, inversions, and gene order at the boundaries of the inverted repeats.

Results: We present the plastome sequences of Equisetum arvense, a horsetail, and of Isoetes flaccida, a heterosporous lycophyte. Phylogenetic analysis of aligned nucleotides from 49 plastome genes from 43 taxa supported monophyly for the following clades: embryophytes (land plants), lycophytes, monilophytes (leptosporangiate ferns + Angiopteris evecta + Psilotum nudum + Equisetum arvense), and seed plants. Resolution among the four monilophyte lineages remained moderate, although nucleotide analyses suggested that $P$. nudum and $E$. arvense form a clade sister to A. evecta + leptosporangiate ferns. Results from phylogenetic analyses of nucleotides were consistent with the distribution of plastome gene rearrangements and with analysis of sequence gaps resulting from insertions and deletions (indels). We found one new indel and an inversion of a block of genes that unites the monilophytes.

Conclusions: Monophyly of monilophytes has been disputed on the basis of morphological and fossil evidence. In the context of a broad sampling of land plant data we find several new pieces of evidence for monilophyte monophyly. Results from this study demonstrate resolution among the four monilophytes lineages, albeit with moderate support; we posit a clade consisting of Equisetaceae and Psilotaceae that is sister to the "true ferns," including Marattiaceae.
\end{abstract}

\section{Background}

Patterns and processes of organic evolution are reflected in the structure and sequences of organisms' genomes. Although we are only starting to accumulate sufficient data to compare nuclear genomes of plants, more data

\footnotetext{
* Correspondence: kkarol@nybg.org

${ }^{1}$ The Lewis B. and Dorothy Cullman Program for Molecular Systematics Studies, The New York Botanical Garden, Bronx, New York 10458, USA Full list of author information is available at the end of the article
}

Full list of author information is avalable at the end of the article are available for the smaller plastid genomes (plastomes). Comparative work on plastomes began in the early 1980's using restriction site mapping and hybridization with heterologous probes to generate phylogenetically informative data within small clades, generally below the family level $[1,2]$ as well as using comparative mapping to examine differences among more distantly related groups [3-6]. By the 1990's the emphasis shifted to nucleotide sequences from targeted regions (genes)

(C) 2010 Karol et al; licensee BioMed Central Ltd. This is an Open Access article distributed under the terms of the Creative Commons Attribution License (http://creativecommons.org/licenses/by/2.0), which permits unrestricted use, distribution, and reproduction in any medium, provided the original work is properly cited. 
with the result that studies with broad genomic sampling were few. However, a reduction in sequencing cost and concomitant development of analytical tools over the past 10 years has resulted in resurgence of comparative plastid genomics.

The plastome is highly conserved in overall structure and this provides the basis for comparative studies [4]. However, there is still sufficient variation to identify rare genomic events that mark critical branches in land plant evolution, thereby elucidating early evolutionary modifications to the plastid genome [e.g., [5,7]]. Plastomes of Marchantia polymorpha [8] and Nicotiana tabacum [9] were the first to be sequenced and within 19 years there were 45 complete plastome sequences for green plants (Viridiplantae) in GenBank [10]. Acceleration of efforts yielded 146 plastome sequences by the end of 2009, with many others in progress.

Complete genome sequences offer several advantages over restriction site maps and nucleotide sequences of targeted regions. In addition to substantially increasing the number of gene sequences for comparison, plastome sequences provide vast structural and evolutionary information that includes gene order, genome rearrangements, patterns of base pair composition, codon usage, mechanisms of gene duplication and gene loss (e.g., pseudogenization), patterns of nucleotide insertion and deletion (indels), and the occurrence of noncoding regions (such as plastome microsatellites and introns). We now have sufficient sampling from most major land plant clades to begin comparative analyses of their plastomes in earnest.

Despite considerable progress over the last 15 years in our understanding of green plant phylogeny, several nodes remain poorly resolved. One example is the monilophytes, which include five major lineages: leptosporangiate ferns, horsetails, marattioid ferns, ophioglossoid ferns and psilophytes. The monilophytes seem to be well-supported as a group, and are generally accepted as sister to seed plants [11-14]. But relationships among the major monilophyte lineages remain unclear. Here we present the complete plastome for the horsetail Equisetum arvense L., representing one of the last major monilophyte lineages to have a representative complete plastome available. For further resolution of land plant relationships and plastome evolution we also sequenced the plastome of Isoetes flaccida Shuttlw. ex A. Braun, the last of the three major lycophyte lineages to be sampled. We use data for 49 genes from 43 green plant taxa to infer phylogenetic relationships of land plants and compile information on the distribution of gene translocations, genomic inversions, gene content and indels to augment the phylogenetic signal from gene variation. We also examine codon usage and base composition. Patterns of plastome architecture are compared across early land plant lineages that diverged 400 to 500 million years ago.

\section{Results and Discussion}

Our analyses included representatives of all major land plant lineages as well as sampling of charophycean green algae for appropriate phylogenetic context. We do not provide detailed comparative plastome analyses for charophycean algae and seed plants because these are presented elsewhere: charophycean green algae $[15,16]$, gymnosperms [17-20] and angiosperms [21-23].

\section{Plastome structures and composition}

Gene maps for plastomes of Equisetum arvense and Isoetes flaccida are shown in Fig. 1. The complete plastome of $E$. arvense is 133,309 base pairs (bp) and includes a 93,542 bp large single-copy (LSC) region, a 19,469 bp small single-copy (SSC) region and two 10,149 bp inverted repeats (IRA and IRB). The complete plastome of I. flaccida is $145,303 \mathrm{bp}$ and includes a $91,862 \mathrm{bp}$ LSC, a 27,205 bp SSC and two 13,118 bp IRs. The overall G/C content is $33.36 \%$ for E. arvense and $37.94 \%$ for I. flaccida. Both annotated plastomes have been deposited in GenBank (Table 1).

\section{Gene content of Isoetes and Equisetum}

Several minor differences in gene content between Equisetum arvense and Isoetes flaccida were identified (Table 2 ). We detected trnS-CGA only in E. arvense, and pseudogenes of rps16, tufA and an extra fragment of $n d h B$ only in I. flaccida. Because of difference in the IR boundaries $E$. arvense has one copy of rps 7 whereas $I$. flaccida has two copies. The position of the IR boundary also results in a small fragment of $y c f 2$ in the IR of $I$. flaccida. The gene $y c f 66$ is in both taxa, but appears to be pseudogenized in $E$. arvense. The genes $a c c D$, infA and rps 2 are also in both taxa but appear to be pseudogenized in I. flaccida.

\section{clpP introns}

In our newly described plastomes, $\operatorname{clpP}$ contains only one intron in Equisetum arvense and two introns in Isoetes flaccida. The distribution of introns in $c l p P$ is variable across plastomes sampled to date: all bryophytes have two introns, lycophytes have either two introns (Huperzia lucidula and I. flaccida) or one intron (Selaginella moellendorffii and S. uncinata), and all monilophytes except $E$. arvense have two introns. Among gymnosperms, Cycas taitungensis has two introns and other gymnosperms have either lost both introns (Pinus thunbergii, Ephedra equisetina and Welwitschia mirabilis) or have lost clpP entirely (Gnetum parvifolium). Most flowering plant $c l p P$ genes have two introns, except the monocot Agrostis calamus. In the charophycean algae, Chara vulgaris and Chaetosphaeridium 


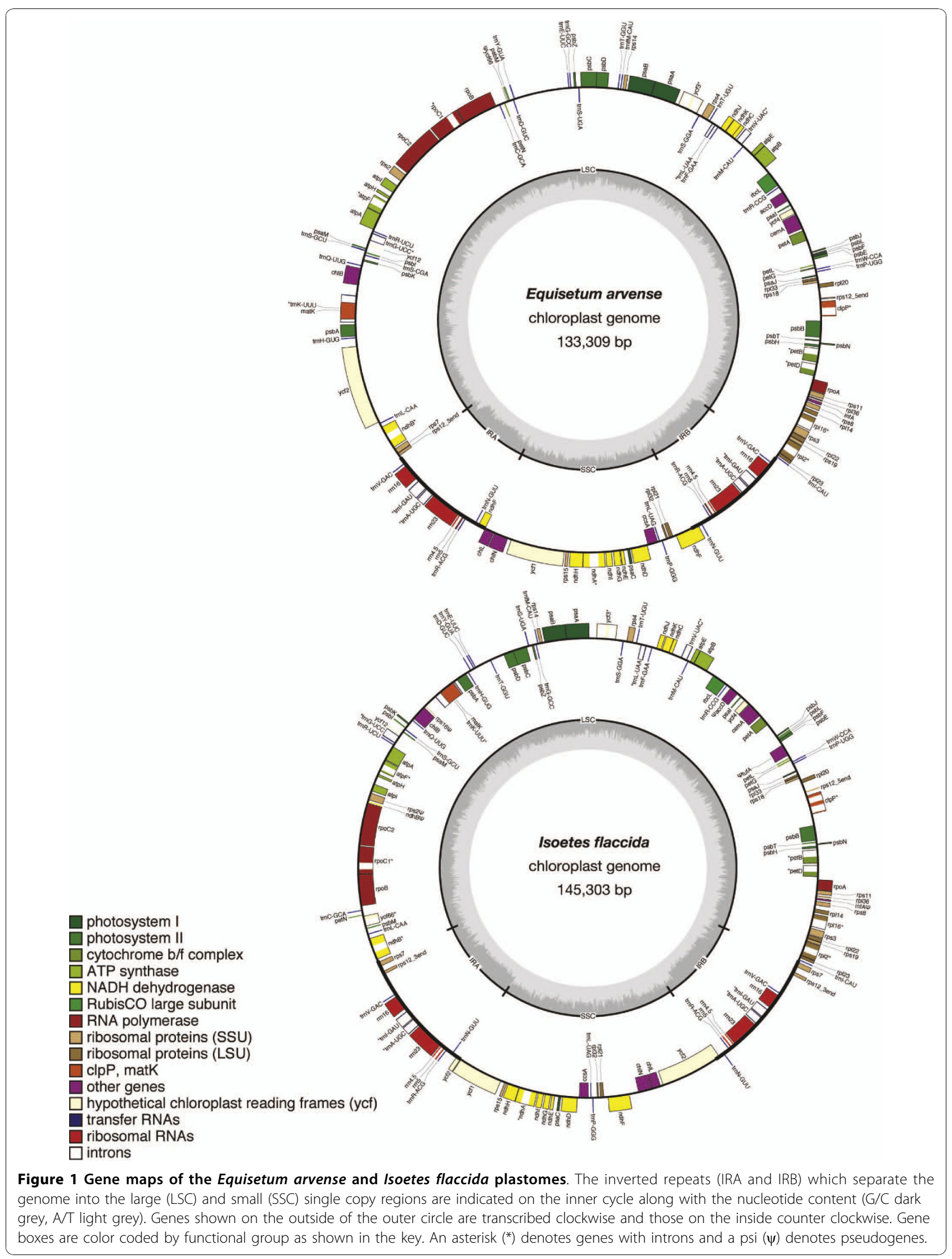


Table 1 List of plastomes analyzed in this study

\begin{tabular}{|c|c|c|c|}
\hline Taxon & GenBank Accession & Plastome size (bp), G/C (\%), ENc & Citation \\
\hline \multicolumn{4}{|l|}{ Angiosperms: } \\
\hline Arabidopsis thaliana & NC_000932 & $154478,40.3,47.90$ & Sato et al. 1999 [68] \\
\hline Morus indica & NC_008359 & $158484,40.5,47.96$ & Ravi et al. 2007 [69] \\
\hline Vitis vinifera & NC_007957 & $160928,41.0,48.64$ & Jansen et al. 2006 [70] \\
\hline Nicotiana tabacum & NC_001879 & $155943,41.0,48.79$ & Shinozaki et al. 1986 [9] \\
\hline Helianthus annuus & NC_007977 & $151104,40.8,48.56$ & Timme et al. 2007 [71] \\
\hline Spinacia oleracea & NC_002202 & $150725,40.7,48.25$ & Schmitz-Linneweber et al. 2001 [72] \\
\hline Ranunculus macranthus & NC_008796 & $155129,41.4,49.68$ & Raubeson et al. 2007 [23] \\
\hline Agrostis stolonifera & NC_008591 & $136584,41.2,49.76$ & Saski et al. 2007 [73] \\
\hline Lemna minor & NC_010109 & $165955,40.1,46.69$ & Mardanov et al. 2008 [74] \\
\hline Phalaenopsis aphrodite & NC_007499 & $148964,40.4,47.83$ & Chang et al. 2006 [75] \\
\hline Dioscorea elephantipes & NC_009601 & $152609,40.5,47.73$ & Hansen et al. 2007 [21] \\
\hline Acorus calamus & NC_007407 & $153821,41.7,49.76$ & Goremykin et al. 2005 [43] \\
\hline Drimys granadensis & NC_008456 & $160604,41.6,49.82$ & Cai et al. 2006 [76] \\
\hline Liriodendron tulipifera & NC_008326 & $159886,41.8,49.67$ & Cai et al. 2006 [76] \\
\hline Illicium oligandrum & NC_009600 & $148553,42.1,50.37$ & Hansen et al. 2007 [21] \\
\hline Chloranthus spicatus & NC_009598 & $157772,41.6,49.65$ & Hansen et al. 2007 [21] \\
\hline Nymphaea alba & NC_006050 & $159930,42.2,50.68$ & Goremykin et al. 2004 [77] \\
\hline Amborella trichopoda & NC_005086 & $162686,41.7,49.66$ & Goremykin et al. 2003 [78] \\
\hline \multicolumn{4}{|l|}{ Gymnosperms: } \\
\hline Pinus thunbergii & NC_001631 & $119707,41.4,48.98$ & Wakasugi et al. 1994 [79] \\
\hline Ephedra equisetina & NC_011954 & $109518,37.5,44.35$ & Wu et al. 2009 [19] \\
\hline Gnetum parvifolium & NC_011942 & $114914,40.2,53.80$ & Wu et al. 2009 [19] \\
\hline Welwitschia mirabilis & NC_010654 & $119726,38.5,45.79$ & Wu et al. 2009 [19] \\
\hline Cycas taitungensis & NC_009618 & $163403,41.7,48.58$ & Wu et al. 2007 [20] \\
\hline Ginkgo biloba & various & N. A., $41.8,48.87$ & Leebens-Mack et al. 2005 [80] \\
\hline \multicolumn{4}{|l|}{ Monilophytes: } \\
\hline Adiantum capillus-veneris & NC_004766 & $150568,44.2,55.12$ & Wolf et al. 2003 [37] \\
\hline Alsophila spinulosa & NC_012818 & $156661,43.6,52.99$ & Gao et al. 2009 [38] \\
\hline Angiopteris evecta & NC_008829 & $153901,39.2,44.32$ & Roper et al. 2007 [27] \\
\hline Psilotum nudum & NC_003386 & $138829,39.3,45.80$ & GenBank direct submission \\
\hline Equisetum arvense & GU191334 & $133309,37.2,41.94$ & This study \\
\hline \multicolumn{4}{|l|}{ Lycophytes: } \\
\hline Selaginella uncinata & AB197035 & $144170,54.3,58.30$ & Tsuji et al. 2007 [35] \\
\hline Selaginella moellendorffii & FJ755183 & $143780,51.2,57.73$ & GenBank direct submission \\
\hline Isoetes flaccida & GU191333 & $145303,41.9,48.84$ & This study \\
\hline Huperzia lucidula & NC_006861 & $154373,40.3,46.66$ & Wolf et al. 2005 [39] \\
\hline \multicolumn{4}{|l|}{ Bryophytes: } \\
\hline Anthoceros formosae & NC_004543 & $161162,38.2,42.21$ & Kugita et al. 2003 [30] \\
\hline Syntrichia ruralis & FJ546412 & $122630,34.5,35.46$ & Oliver et al. (in press) [32] \\
\hline Physcomitrella patens & NC_005087 & $122890,35.1,36.12$ & Sugiura et al. 2003 [33] \\
\hline Marchantia polymorpha & NC_001319 & $121024,34.0,35.25$ & Ohyama et al. 1986 [8] \\
\hline \multicolumn{4}{|l|}{ Charophyte Algae: } \\
\hline Staurastrum punctulatum & NC_008116 & $157089,37.1,38.28$ & Turmel et al. 2005 [81] \\
\hline Zygnema circumcarinatum & NC_008117 & $165372,39.2,42.45$ & Turmel et al. 2005 [81] \\
\hline Chaetosphaeridium globosum & NC_004115 & $131183,35.0,36.95$ & Turmel et al. 2002 [82] \\
\hline Chara vulgaris & NC_008097 & $184933,35.7,39.57$ & Turmel et al. 2006 [83] \\
\hline Chlorokybus atmophyticus & NC_008822 & $152254,39.1,43.85$ & Lemieux et al. 2007 [15] \\
\hline Mesostigma viride & NC_002186 & $118360,34.9,34.83$ & Lemieux et al. 2000 [84] \\
\hline
\end{tabular}

GenBank accession numbers, plastome sizes in base pairs (bp), percent $\mathrm{G} / \mathrm{C}$ content, effective number of codons (ENc) and original citations are shown. 
Table 2 List of plastid genes and pseudogenes annotated for Equisetum arvense and Isoetes flaccida

\begin{tabular}{|c|c|c|c|c|}
\hline Gene class & & & & \\
\hline Ribosomal RNAs & $r r n 4.5 \times 2$ & $\operatorname{rrn} 5 \times 2$ & $\operatorname{rrn} 16 \times 2$ & $r r n 23 \times 2$ \\
\hline \multirow[t]{9}{*}{ Transfer RNAs } & $\operatorname{trn} A-U G C^{*} \times 2$ & $\operatorname{trn} C-G C A$ & $\operatorname{trn} D-G U C$ & $\operatorname{trnE-UUC}$ \\
\hline & $\operatorname{trnF-GAA}$ & $\operatorname{trnG-GCC}$ & $\operatorname{trnG-UCC^{*}}$ & $\operatorname{trnH}$-GUG \\
\hline & $\operatorname{trnl}-\mathrm{CAU}$ & trnl-GAU* $\times 2$ & $\operatorname{trnK} K \cup \cup U^{*}$ & $\operatorname{trn} L-C A A$ \\
\hline & $\operatorname{trn} L-U A A^{*}$ & $\operatorname{trnL}-U A G$ & $\operatorname{trnM}-\mathrm{CAU}$ & $\operatorname{trnfM}-\mathrm{CAU}$ \\
\hline & $\operatorname{trnN}-G \cup \cup \times 2$ & $\operatorname{trn} P-G G G$ & $\operatorname{trn} P-U G G$ & $\operatorname{trn} Q-U U G$ \\
\hline & $\operatorname{trn} R-A C G \times 2$ & $\operatorname{trn} R-C C G \mathrm{C}$ & $\operatorname{trnR}-U C U$ & $\operatorname{trnS}-C G A$ in $E a$ \\
\hline & $\operatorname{trnS}-G C U$ & $\operatorname{trnS-GGA}$ & $\operatorname{trnS}-U G A$ & $\operatorname{trnT-GGU}$ \\
\hline & $\operatorname{trnT} T-U G U$ & $\operatorname{trnV}-G A C \times 2$ & $\operatorname{trn} V-U A C^{*}$ & $\operatorname{trnW}-C C A$ \\
\hline & $\operatorname{trnY} Y-G \cup A$ & & & \\
\hline \multirow[t]{2}{*}{ Photosystem I } & psaA & psaB b & psaC & psal b \\
\hline & psaJ & psaM & & \\
\hline \multirow[t]{4}{*}{ Photosystem II } & $p s b A$ & $p s b B$ & $p s b C$ & $p s b D$ \\
\hline & $p s b E$ & $p s b F$ & psbH b & psbl \\
\hline & $p s b J$ & $p s b K$ & $p s b L b$ & psbM \\
\hline & $p s b N$ & psbT b & $p s b Z$ & \\
\hline \multirow[t]{2}{*}{ Cytochrome } & petA & $\operatorname{pet}^{*} \mathrm{~b}, \mathrm{e}$ & $\operatorname{pet} D^{*} \mathrm{~b}, \mathrm{e}$ & petG $\mathrm{b}$ \\
\hline & petL & $\operatorname{petN} b$ & & \\
\hline \multirow[t]{2}{*}{ ATP synthase } & atpA & $\operatorname{atp} B$ & atpE & $a t p F^{*}$ \\
\hline & atpH & $a t p l b$ & & \\
\hline Rubisco & $r b c L b$ & & & \\
\hline Chlorophyll biosynthesis & $C h / B$ & chll b & $c h / N$ & \\
\hline \multirow[t]{3}{*}{ NADH dehydrogenase } & $n d h A^{*} \mathrm{~b}$ & $n d h B^{*}$ & $n d h C$ & $n d h D$ b, i \\
\hline & ndhE & $n d h F \mathrm{i}$ & $n d h G$ & $n d h H \mathrm{~b}$ \\
\hline & $n d h l$ & $n d h J \mathrm{i}, \mathrm{e}$ & $n d h K$ & \\
\hline \multirow[t]{6}{*}{ Ribosomal proteins } & $r p / 2^{*}$ & $r p / 14 \mathrm{~b}, \mathrm{i}, \mathrm{e}$ & $r p / 16^{*}$ & rp/20 b \\
\hline & $r p / 21 \mathrm{i}$ & $r p / 22$ & $r p / 23$ & $r p / 32$ \\
\hline & $r p / 33$ & $r p / 36$ & $\operatorname{rps} 2 \psi(\mathrm{If})$ & rps3 \\
\hline & rps4 b & rps7 $\times 2$ in If & rps8 b & rps11 b, s \\
\hline & $\operatorname{rps} 12 \times 2 \mathrm{tr}$ & rps 14 & rps15 & $\operatorname{rps} 16 \psi$ in If \\
\hline & rps18 & rps19 & & \\
\hline RNA polymerase & rpoA i & rpoB i & $r p o C 1^{*}$ i & rpoc2 i \\
\hline \multirow[t]{2}{*}{ Miscellaneous proteins } & $\inf A \psi(I f)$ & $\operatorname{ccs} A b$ & matk & $c l p p^{*}$ \\
\hline & $\operatorname{accD} \psi(I f), s s$ & $\operatorname{cem} A \mathrm{i}$ & tufA $\psi$ in If & \\
\hline \multirow[t]{2}{*}{ Hypothetical proteins } & $y c f 1 b$ & $y c f 2 i$ & $y c f 3^{*}$ & ycf $\mathrm{b}$ \\
\hline & ycf12 & $y c f 66^{*} \psi(E a)$ & & \\
\hline Duplicate gene fragments & $n d h B \psi$ in If & $y c f 2 I R$ in If & $n d h F \mathbb{R}$ in $E a$ & \\
\hline
\end{tabular}

* = intron-containing gene; $\operatorname{tr}=$ trans-spliced. In If = gene in I. flaccida but not E. arvense; in Ea = gene in E. arvense but not $I$. flaccida. Hypothesized RNA editing in I. flaccida: $\mathrm{b}=$ start edited; $\mathrm{i}=$ internal stop codon; $\mathrm{e}=$ stop codon edited; $\mathrm{c}=$ anticodon of tRNA edited. In $E$. arvense: $\mathrm{s}=$ start edited; $\mathrm{ss}=$ start and stop edited. $\psi$ (If) = pseudogene in I. flaccida and gene present in E. arvense but not as pseudogene. $\psi$ in If = pseudogene in $I$. flaccida but gene absent in E. arvense. $\psi(E a)=$ pseudogene in E. arvense and gene present in I. flaccida but not as pseudogene. Note that rps7 is in the IR in I. flaccida so has two copies (x2) but only one copy in E. arvense. Genes in bold were those used for phylogenetic analyses.

globosum each have one clpP intron, whereas other charophycean green algae have no introns in $c l p P$. It appears that the second $c l p P$ intron is unique to land plants, although there have been several lineage-specific losses (e.g., Selaginella spp., E. arvense, most gymnosperms, and at least one lineage of monocots).

\section{tufA in land plant plastomes}

The functional tufA gene is encoded in the plastid genome of most green algae but has been transferred to the nuclear genome in land plants and certain charophycean green algae [24-26]. A tufA-like fragment was identified in Anthoceros formosae, cycads and Gingko biloba plastomes situated between $p s b E$ and petL [20]. We found a 1,364-bp region between $p s b E$ and petL in Isoetes flaccida that shares $41 \%$ nucleotide similarity with the plastid encoded tufA gene found in Chara vulgaris. The I. flaccida tufA homologue lacks the expected start and stop codons and contains 29 internal stop codons within the 
reading frame. Furthermore, when this region was aligned with the $C$. vulgaris homologue, 38 indels were identified (Additional File 1). Taken together, the I. flaccida tufA-like region is most likely a pseudogene. These relictual fragments of a once functional plastid gene now identified in four distantly related land plant lineages (i.e., hornworts, lycophytes and two gymnosperms) offer an interesting opportunity to study patterns of plastome gene loss as well as the process of gene decay.

\section{Putative RNA editing}

Reliable inferences on RNA editing require comparisons of genomic sequence to that of mature mRNA or cDNA. However, a fraction of editing sites are in start or stop codons, or result in premature stop codons, thus providing a hint of RNA editing from genomic sequences. We found such evidence in two genes in Equisetum arvense and 28 genes in Isoetes flaccida (Table 2). The former had an undetermined start codon for rps11 and undetermined start and stop codons for $a c c D$. In I. flaccida we found 21 loci with undetermined start codons, two with undetermined stop codons, and seven internal stop codons. Based on the sequence of $\operatorname{trnR}$-CCG, we also infer that the second position of the anticodon is RNA edited (U- $>$ C).

ycf1

The region between $c h l N$ and rps 15 in plastomes presents an interesting challenge. In certain taxa this region contains two putative protein-coding genes, both read from the same DNA strand, but in different reading frames. Other taxa, including Equisetum arvense and Isoetes flaccida, contain a single large open reading frame (orf) commonly annotated as $y c f 1$. Recent interpretation of the interruption of $y c f 1$ has been either to recognize the entire region as a $y c f 1$ pseudogene [e.g., [27]], or to recognize the larger of the two orfs as $y c f 1$ while leaving the smaller unannotated [e.g., [28]]. The function of these orfs (or orf) is unknown and there are at least two processes that explain the differences in putative orfs in this region of the plastome. One possibility is that the large orf could yield two separate protein products through a post-transcription edit that adds a stop codon. Another possibility is that the two-orf pattern is a result of a frame shift that can be read through during translation, yielding a single protein product [e.g., [29]]. However, transcripts of this region have been determined for Anthoceros formosae with two-orfs and Adiantum capillus-veneris with a single large orf $[30,31]$. These transcript data were consistent with the original DNA annotation. That is, the reading frame was not 'corrected' in Anthoceros formosae and an internal stop codon was not detected in the larger orf in Adiantum capillusveneris. Therefore at both the DNA and the RNA transcript levels there appears to be two alternative patterns.

\section{Gene order}

Comparative plastome maps for representative early diverging land plant lineages are shown in Fig. 2. The liverwort Marchantia polymorpha was not included in this figure because it shares similar gene order with the moss Syntrichia ruralis and the hornwort Anthoceros formosae.

\section{Bryophytes}

Previous reports of plastomes representing exemplar bryophytes (liverwort Marchantia polymorpha, mosses Physcomitrella patens and Syntrichia ruralis, hornwort Anthoceros formosae) have shown that plastome content and gene order are highly conserved [8,30,32,33]. This is true even in Aneura mirabilis, the only non-photosynthetic bryophyte [28]. One exception was reported in $P$. patens, involving a large inversion $(\sim 71 \mathrm{~kb})$ encompassing nearly the entire LSC relative to a sample of four other mosses [33]. Goffinet et al. [34] surveyed the phylogenetic extent of the $P$. patens inversion and found it was restricted to the moss order Funariales. Oliver et al. [32] found that the moss S. ruralis does not have this large inversion but instead has the ancestral land plant plastome gene order.

\section{Lycophytes}

The plastomes of Isoetes flaccida and Huperzia lucidula (lycophytes) share similar gene order with bryophytes. However, we identified two unique structural changes in I. flaccida (Fig. 2). First, ycf2 in I. flaccida, which normally resides in the LSC in most land plant plastomes, has been translocated to the SSC with the 5' end now incorporated into the IR. Second, the $\operatorname{chlL} / \mathrm{chlN}$ gene cluster has been inverted in I. flaccida and now resides adjacent to $y c f 2$ rather than $y c f 1$ as in H. lucidula. Neither the $y c f 2$ translocation nor the chlL/chlN inversion occurs in either of the Selaginella plastomes.

Both Selaginella plastomes are considerably different in gene order from typical land plant plastomes (Fig. 2) [[35], Banks et al. personal communications]. A large region $(\sim 14-\mathrm{kb})$ has been translocated from the LSC to the IR/SSC in both plastomes, although the genes included in this translocation differ slightly. In both Selaginella plastomes, rps4 marks one endpoint of this translocated segment and this gene now resides in the IR. The other endpoint resides in the SSC and is marked by $p s b D$ in $S$. moellendorffii and by three additional genes (trnE-UUC, trnY-GUA and trnD-GUC) in S. uncinata. These tRNA genes remain in the LSC adjacent to $y c f 2$ in S. moellendorffii, as is the case in most land plant plastomes. Several unique features were identified in the plastome of $S$. uncinata including a $\sim 20-\mathrm{kb}$ LSC inversion ( $p s b I$ to rpoB-trnC-GAC), duplication of $p s b K$ and $\operatorname{trn} Q-U U G$, and translocation of petN from the LSC to the SSC [35]. 


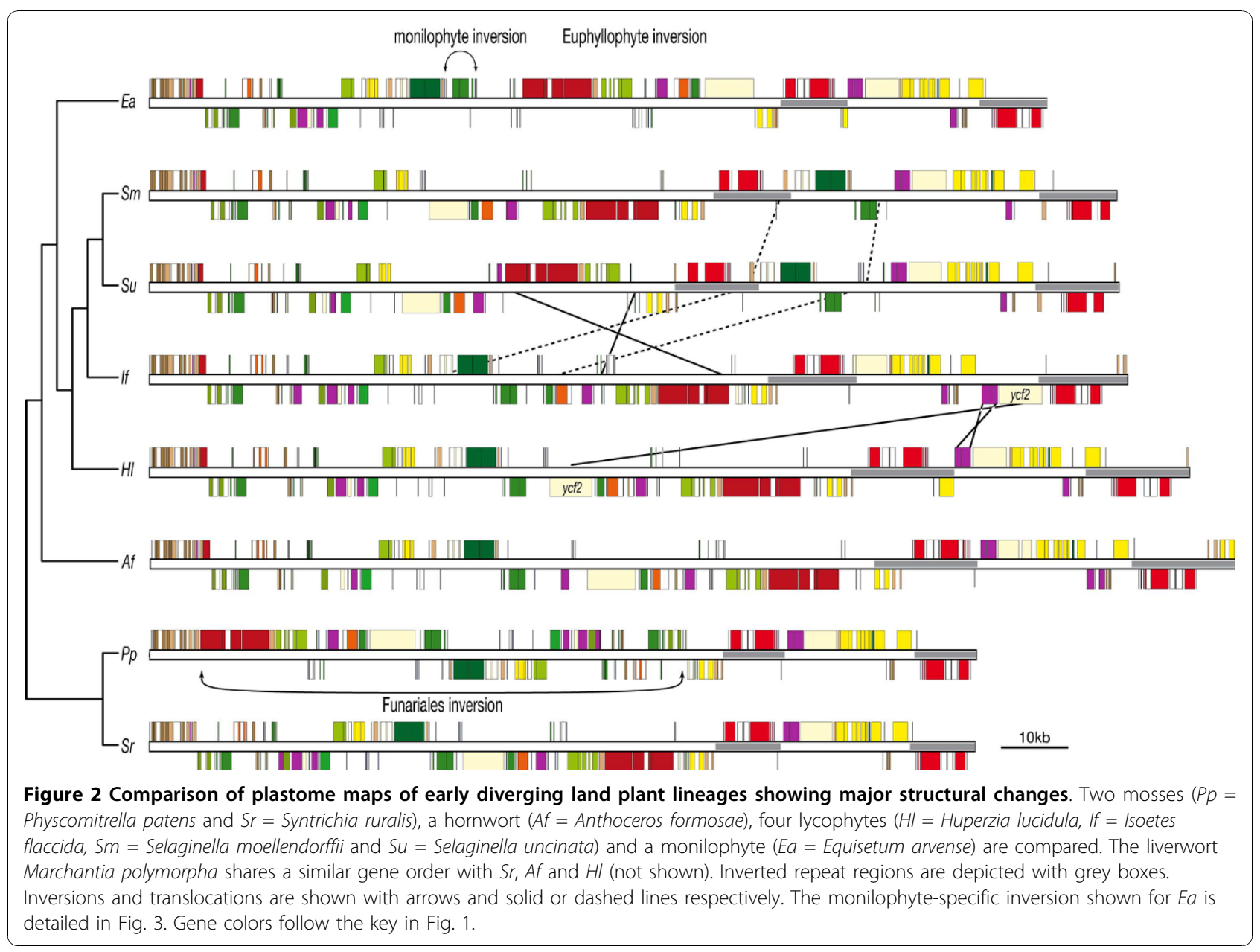

\section{Euphyllophytes}

Raubeson and Jansen [5] identified a 30-kb LSC inversion marking the euphyllophytes as a monophyletic group to the exclusion of the lycophytes. This inversion is confirmed in all monilophyte (including Equisetum arvense, Fig. 2) and seed plant plastomes sequenced and does not occur thus far in bryophyte or lycophyte plastomes (including Isoetes flaccida, Fig. 2).

\section{Monilophytes}

Taking into account lineage specific gene losses and differences in IR gene content, Angiopteris evecta, Equisetum arvense and Psilotum nudum share identical gene order. Two large inversions associated with the IR and two smaller inversions in the LSC characterize the plastome of Adiantum capillus-veneris [36,37]. The tree fern Alsophila spinulosa shares these inversions [38], indicating that they probably occurred in the ancestor to a clade that includes most extant leptosporangiate ferns. Comparative gene-order analyses identified one of the LSC inversions (involving trnG-GCC to trnT-GGU) in Psilotum nudum, Angiopteris evecta and leptosporangiate ferns $[27,38,39]$. Here we identified the same inversion in Equisetum arvense, further supporting the hypothesis that this inversion is shared by all extant monilophyte taxa and can serve as a reliable molecular marker for the monophyly of this lineage (Fig. 3). Neither of the two IR inversions nor the remaining LSC inversion found in Adiantum capillus-veneris and Alsophila spinulosa was identified in other monilophyte plastomes.

\section{The inverted repeat boundaries}

Most plastome IRs have similar gene content that primarily includes rRNA and tRNA genes $[16,22,40]$. This is the case even in the ferns that have a reorganized IR $[37,38]$. Variation from the typical IR gene content has been explained by movement ("ebb and flow") of the IR boundaries into, and out of, the LSC and SSC regions [41]. In our broad sample of land plant plastomes we found several taxa with unique IR boundaries that differ from the basic theme (Fig. 4). In some cases, distantly related taxa have very similar IR boundaries. The liverwort and the two mosses are identical in gene content at both ends of the IR. The two distantly related ferns are also identical to each other. Similarities at only one 


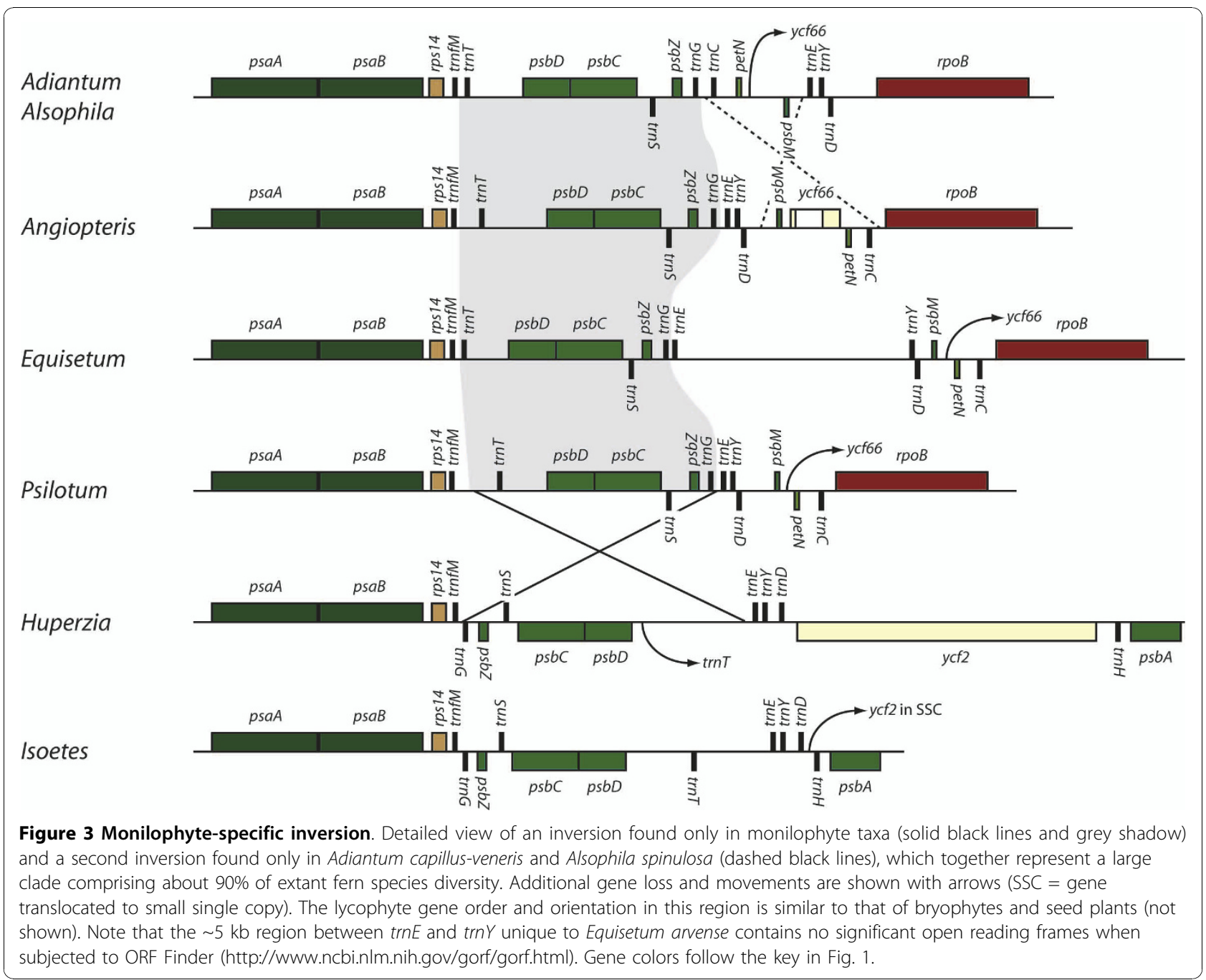

end of the IR are seen in a wider range of taxa. One end of the LSC is bounded by trnI-CAU in all seed-free land plants in our study, except Selaginella spp. (because they have lost many or their tRNA genes including trnI$C A U$ ) and Angiopteris evecta. The SSC is bounded by $n d h F$ at one end and chlL at the other, in most taxa. This suggests that whereas the ends of the IR clearly ebb and flow in some lineages, in other lineages they appear to be rather stable.

\section{Phylogenetic Analyses}

We analysed four datasets that included 49 proteincoding genes and each was subjected to Maximum Likelihood (ML) and Bayesian Inference (BI). The datasets differed by the number of taxa included: one data set included all taxa listed in Table 1, another excluded both Selaginella species, another excluded all three gnetophyte taxa (Ephedra equisetina, Gnetum parvifolium and Welwitschia mirabilis) and the final excluded both
Selaginella spp. and all gnetophyte taxa. Selaginella spp. and the gnetophytes were selectively included or excluded because of their unusual evolutionary patterns (e.g., plastomes with relatively high G/C content in Selaginella spp. and accelerated divergence rates in gnetophytes; [[18,19,35], Banks et al. personal communications], which can be problematic for phylogenetic reconstruction). Nearly identical topologies were recovered using nucleotide data regardless of analytical method (ML and BI) or taxon set (exclusion of Selaginella spp. and/or gnetophytes) with two exceptions discussed below. A summary including alternate topologies and support values is shown in Fig. 5A-C. Phylogenetic results for angiosperms are shown in Additional file 2.

Phylogenetic relationships among the major bryophyte lineages have been controversial with nearly every possible topology being reported, often with strong support. However, recent convergence in results supports hornworts as sister to vascular plants (as seen here) and 
liverworts sister to all other land plants $[[7,42]$ and references therein]. Monophyly of the bryophytes has also been proposed using plastome gene data. However this relationship was only found when inferred amino acid sequences or protein plus DNA sequences corrected for A-T bias were analyzed [[15,43,44], Additional file 3]. A sister relationship between mosses and liverworts was proposed previously based on morphological 


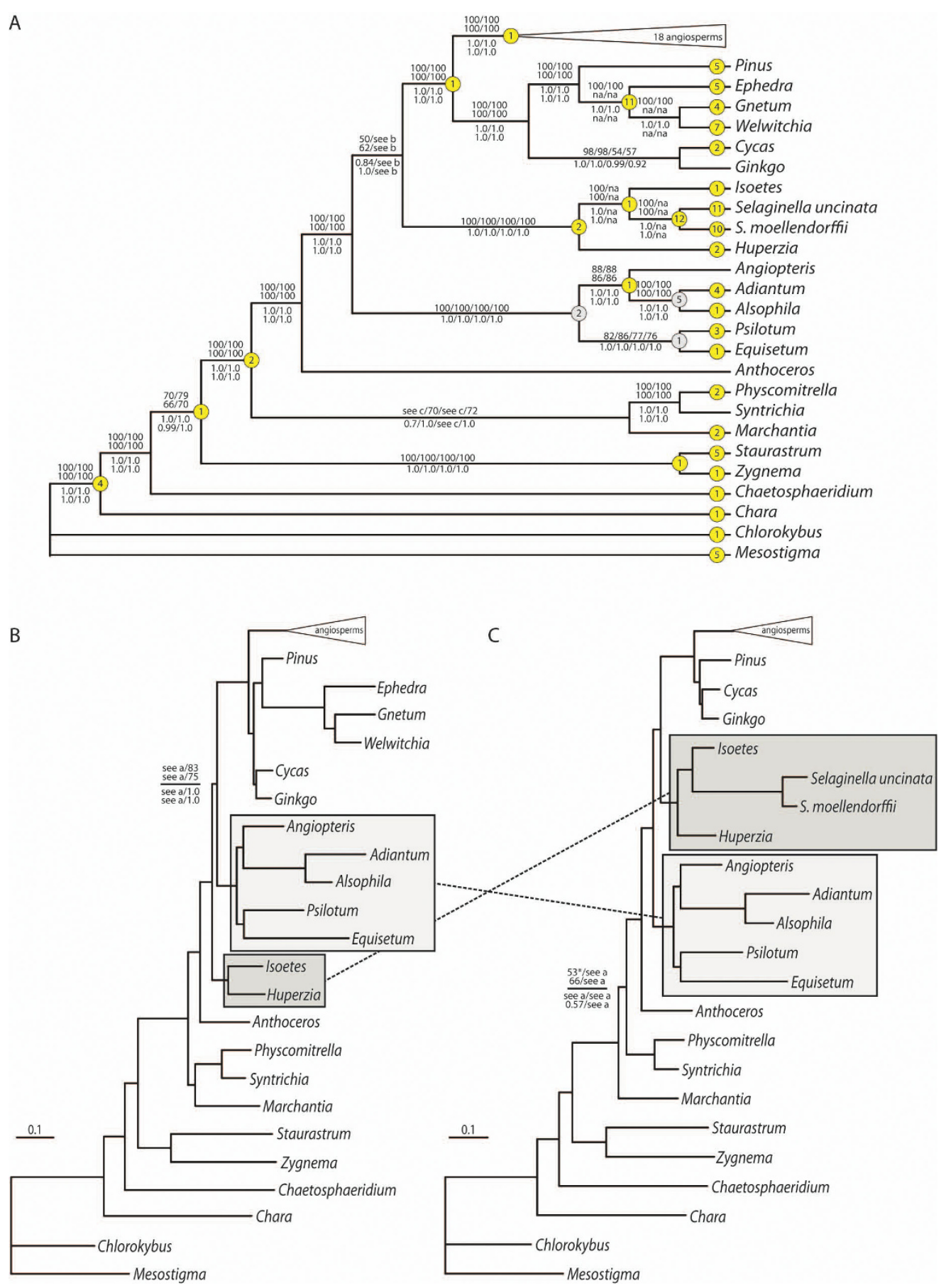

Figure 5 Phylogenetic results using nucleotide data. A) Cladogram based on ML analysis (-In = 473022.24372) of 49 gene sequences from all 43 plastomes sampled (Table 1). Mapped non-homoplastic indels are shown in yellow circles. Numbers in grey circles are indels identified with a more restrictive taxon sampling that were difficult to score across all charophycean green algae and land plants. B) Phylogram based on ML analysis (-In $=442145.83514$ ) of gene sequences, excluding the two Selaginella species. C) Phylogram based on ML analysis (-In $=436696.62372)$ of gene sequences, excluding the three gnetophyte taxa (Ephedra equisetina, Gnetum parvifolium and Welwitschia mirabilis). ML phylogenetic results (-In $=405904.24872)$ that excluded Selaginella spp. and gnetophytes were similar in topology to $b$ (not shown). Numbers above the branches are ML bootstrap proportions and numbers below are Bayesian posterior probabilities in this order: all taxa included/Selaginella spp. excluded/gnetophytes excluded/Selaginella spp. and gnetophytes excluded. The asterisk (*) in c indicates the ML bootstrap proportion for Marchantia polymorpha sister to the remaining land plants found in bootstrap analyses that included all taxa, though the best ML tree recovered a sister relationship of M. polymorpha with the mosses Physcomitrella patens and Syntrichia ruralis. Boxes and dashed lines indicate the relative position of monilophytes (light grey) and lycophytes (dark grey). 
and molecular data. Renzaglia and Garbary [45] concluded that characters related to sperm cell development were compelling evidence for the monophyly of mosses plus liverworts, a clade they referred to as Setaphytes. In a recent analysis that included seven genes from all three DNA compartments (plastid, mitochondria and nuclear) for 192 land plant and green algal taxa, the liverworts were found with strong support as sister to all remaining land plants [12].

In the nucleotide analyses presented here, regardless of taxon set or analytical method, monophyly of land plants was confirmed, as was the sister relationship between the hornwort Anthoceros formosae and tracheophytes (e.g., lycophytes, monilophytes, gymnosperms and angiosperms; Fig. 5). More problematic is the position of liverworts among bryophytes as our results show two taxon-dependent placements of the liverwort Marchantia polymorpha. In ML and BI analyses that included all taxa or excluded Selaginella spp., with or without gnetophytes, M. polymorpha was sister to the mosses Physcomitrella patens and Syntrichia ruralis (Fig. 5A, 5B). The alternative topology with liverworts sister to the remaining land plants was supported in the present study only when the gnetophytes were excluded (Fig. 5C). ML bootstrap proportions were generally weak for this part of the tree regardless of taxon exclusion and BI posterior probabilities were low with the analysis that included all taxa and the analysis that only excluded the gnetophytes. Increased taxon sampling is critical in resolving the pattern of these ancient divergences.

The lycophytes (Huperzia lucidula, Isoetes flaccida, with or without Selaginella spp.) and monilophytes (Adiantum capillus-veneris, Alsophila spinulosa, Angiopteris evecta, Equisetum arvense and Psilotum nudum) were each strongly supported monophyletic groups (Fig. 5). However, the relationships of these two clades to each other and to seed plants varied across our analyses. The monilophytes were sister to the seed plants only when Selaginella spp. were excluded, with or without gnetophytes (Fig. 5B). Alternatively, the lycophytes were supported (weakly in most analyses) as sister to seed plants when Selaginella spp. were included (Fig. 5A, 5C). Strong support was recovered for the monilophyte + seed plant relationship by Qiu et al.[12] and this relationship is further supported by the large plastid LSC inversion identified in monilophytes and seed plants and not found in lycophytes (Fig. 2 discussed above) [5,39]. Within the lycophyte clade, the homosporous $H$. lucidula was consistently sister to the heterosporous taxa I. flaccida and Selaginella spp. (or sister to just I. flaccida in analyses where Selaginella spp. were excluded).

Strongly supported resolution among the major monilophyte lineages has been elusive, and it was not clear if lack of support was a function of insufficient phylogenetic signal, rapid radiation that is indistinguishable from a true polytomy, or ancient extinctions resulting in long-branch taxa that make phylogenetic reconstruction challenging. Our analyses that used 43,491 nucleotide characters (and several subpartitions of these) revealed a moderately supported sister relationship between Psilotum nudum and Equisetum arvense. Although these groups are usually not found as sister lineages, this topology is reasonable given the lack of sampling of sister taxa to both genera. More typically, $P$. nudum is found in a lineage that is sister to ophioglossoid ferns $[12,13,46]$, a lineage not sampled in this study, and these two lineages are found sister to the remaining monilophytes (marattioid ferns, horsetails and leptosporangiate ferns). However, a sister relationship between Psilotaceae and Equisetaceae was recently reported in a phylogenetic analysis of morphological characters across vascular plants where five unambiguous character state changes for the two groups were identified [47]. These were primarily characters associated with leaves and organization of the shoot system. Schneider et al. [47] did not find the same relationship from an analysis of the same taxa using nucleotide sequences, and they cautioned that the morphological evidence for this sister relationship could well be a function of homoplasy and structural simplification reverting to a pleisiomorphic state, thus causing "concern for a possible misleading bias." Failure of so many studies to resolve relationships among the main lineages of monilophytes is consistent with a rapid radiation (i.e., very short internal branches) rather than lack of phylogenetic signal. Additional data from Tmesipteris (a close relative of Psilotum), ophioglossoid ferns, and additional Equisetum species may help to resolve these nodes.

Some of the deep branching events in the land plant tree are still poorly resolved even with full plastome sequence data now available from most of the major clades. It is likely this is because the intervals of shared history among these major clades were relatively short as compared to their subsequent separate histories, giving rise to extreme asymmetry in branch lengths which causes known problems with inferring the correct tree particularly using data with a small number of character states such as nucleic acid sequence data [48]. Rare genome structural changes such as gene-order rearrangements have the potential for resolving such short internal branches [49]. Indeed a phylogenetic analysis of plastome gene-order data found liverworts sister to all other land plants and monilophytes sister to the seed plants [50]. However, in that study the lycophytes were not resolved as a monophyletic group as they are here. This topological convergence suggests that a future combined analysis with nucleotide, structural and 
morphological data may be able to resolve some of the short internal branches.

\section{Indels}

Many genes contained three base-pair indels with apparent phylogenetic signal. We examined all aligned gene sequences for potential indels across the entire taxon sample, scoring characters as 1 for presence or 0 for absence of a sequence stretch. We scored 152 indels (see Additional files 4 and 5); 40 support the phylogenetic tree (synapomorphic), 99 are unique to a terminal taxon (autapomorphic) and 13 contradict the tree (homoplastic). The synapomorphic and autapomorphic indels are presented in Fig. 5A; the 13 homoplastic indels are not mapped. Indels alone, analyzed by MP, did not provide a well-resolved tree (not shown). However, several nodes were supported by uncontradicted indels; land plants (2 indels), lycophytes (2 indels), Selaginella spp. + Isoetes flaccida (1 indel), Selaginella spp. (12 indels), Angiopteris evecta + Adiantum capillusveneris + Alsophila spinulosa ( 1 indel), seed plants ( 1 indel), gnetophytes (11 indels) and angiosperms (1 indel). Angiosperm-specific indels are shown in Additional file 2. Interpretation of indels is dependent on taxon sampling. When subsets of the data were examined more closely we could score additional indels that were difficult to interpret at the broader level. Several such indels were identified; focusing on the monilophytes we found two indels (in atpA and rps4) uniting the monilophytes; the rps4 indel has been reported previously [11]. Five indels in $p s b T$, petG, atpA, rpl16 and rрoB uniting Adiantum capillus-veneris + Alsophila spinulosa, and one in rpl16 uniting Equisetum arvense and Psilotum nudum were also identified (Fig. 5A).

\section{Nucleotide composition and codon usage}

Codon usage bias is often correlated with genomic nucleotide composition bias but may also be correlated with gene expression, selection and drift $[51,52]$. The overall G/C content of the genes used in our phylogenetic analyses ranged from 34\% in Marchantia polymorpha to $54 \%$ in Selaginella uncinata. Both S. uncinata and $S$. moellendorffii were remarkable for their high (greater than 50\%) G/C content. Among land plants included in this study, only $M$. polymorpha and the mosses contain less than $35 \% \mathrm{G} / \mathrm{C}$. The nucleotide composition bias found in many plastomes may result in codon usage biases as well.

The effective number of codons (ENc) is often used as a measure of the amount of codon bias within a gene or genome [53] with values ranging from 20 (very biased) to 61 (very unbiased). Most vascular plants in our study had a value between 46 and 50 (Table 1). Less bias was detected in Adiantum capillus-veneris $(\mathrm{ENc}=55.12)$, Alsophila spinulosa (52.99), Selaginella uncinata (58.30) and S. moellendorffii (57.73). More bias was found in bryophytes and charophycean algae, notably Marchantia polymorpha (35.25), Physcomitrella patens (36.12) and Syntrichia ruralis (35.46). These differences may have ramifications for the estimation of phylogenetic relationships among these groups.

\section{Conclusions}

This study illustrates the advantage of whole plastome sequences for studies of plastome architecture and land plant evolution. Nucleotide sequence data from targeted regions have contributed greatly to our understanding of plant phylogeny. However short sequence data can have limitations because they can miss important aspects of genome structure, and nucleotide substitution rates are not always applicable to solving specific evolutionary questions. Restriction site mapping also is limiting because it usually requires a series of cross comparisons every time a taxon is added. Complete plastome sequences provide data that can be used for nucleotidebased analyses, but also can add to a growing database of structural genomic data, including inversions, gene content, and indels. New taxa can be added relatively easily without additional experimental comparisons. Also, changes that might first appear to characterize a large clade might turn out to be more restricted once additional taxa are sampled. For example, some of the unique structural attributes first identified in Selaginella uncinata plastome [35] appear to be unique (so far), whereas others are shared with a second plastome sequence of $S$. moellendorffii (Banks et al. personal communications). Another important aspect of this type of data is that changes that first appear autapomorphic in small datasets might later emerge as key synapomorphies as additional taxa are sampled. This is illustrated by the series of large inversions in the IR first identified in Adiantum capillus-veneris [36,37] but later shown to be shared with the distantly related tree fern Alsophila spinulosa [38], and by inference shared among more than $90 \%$ of leptosporangiate fern species.

Most of the currently available plastome sequences are from seed plants, with very few available from the presumed sister clade, the monilophytes. Here we have added an additional monilophyte plastome sequence as well as a lycophyte plastome sequence that represent two critical lineages that were not previously sampled (i.e., Equisetaceae and Isoetaceae). We examine multiple aspects of these plastomes to reveal patterns of evolution across land plants. We demonstrate that comparative plastome analysis can provide valuable information about evolutionary processes at the nucleotide, gene and genome scale in early land plants. These data are phylogenetically informative at many levels. Gene rearrangement and indels are informative at deep nodes. Plastome sequences also provide valuable nucleotide 
data that can be used in studies of ancient and more recent divergences.

Now that plastome sequence data are available for most major lineages of early land plants additional sampling can focus on resolution of poorly supported nodes by increased taxon sampling within these lineages. Although we have one or two representatives of each major group, these often represent lineages containing hundreds or thousands of species. Additional sampling within species-rich lineages may resolve some areas of phylogenetic conflict. As DNA sequencing costs continue to decrease it will become possible to improve sampling and gain further insight into early land plant evolution as well as the patterns and processes that shape the evolution of plastomes.

\section{Methods \\ Taxa}

We compared and analyzed complete plastid genomes of 43 taxa, including 37 land plants and six charophycean algae (Table 1). Two of the land plant plastomes are new to this study (herbarium vouchers at WTU): Equisetum arvense and Isoetes flaccida. For E. arvense and I. flaccida, tissue preparation, plastid isolation, DNA extraction, cloning, sequencing, and assembly followed Wolf et al.[39]. Annotation was carried out with DOGMA [54] and tRNAscan [55].

\section{Plastome analyses}

Gene maps for representative plastomes were drawn with OGDraw and compared for gene content, gene order and IR boundaries [56]. Codon usage and nucleotide frequencies were determined using CodonW [57].

\section{DNA alignment}

Nucleotide sequences for the 49 protein-coding genes found in all study taxa were extracted from DOGMAannotated plastomes or from those found in GenBank (Table 1). The hornwort Anthoceros formosae and the fern Adiantum capillus-veneris both have extensive RNA editing [30,36,37]. Therefore, we used the cDNA sequences rather than genomic sequences for phylogenetic analysis. Each gene was aligned with MacClade v4 [58] and the resulting individual gene alignments were assembled into a single data matrix. A Nexus block was written that identified all unalignable DNA regions, overlapping gene regions, and inferred RNA edited stop codons for exclusion in subsequent phylogenetic analyses. Indels were scored in a separate data matrix as binary characters.

The resulting 49-gene alignment including all codon positions (see Additional file 5) was partitioned into four data sets, 1) one that included all 43 taxa and 30,018 characters, 2) one that excluded both Selaginella species (41 taxa and 29,961 characters), 3) one that excluded the gnetophytes Ephedra equisetina, Gnetum parvifolium and Welwitschia mirabilis (40 taxa and 29,871 characters), and 4) one that excluded both Selaginella species and all gnetophytes (38 taxa and 29,814 characters). Altering the taxon set changes the number of characters because of lineage specific indels. Nucleotide alignments were translated into amino acids using MacClade assuming the universal code [58]. Ambiguous amino acids resulting from polymorphic nucleotides were treated as missing.

\section{Phylogenetic Analyses}

Maximum Likelihood (ML) and Bayesian Inference (BI) analyses were performed on each of the four nucleotide data sets using PAUP* v4.0b10 [59] and MrBayes v3.1.2 [60-62], respectively. MrModeltest v2 [63] was used to determine the best fitting model of DNA substitution. With the best fitting model $(G T R+I+\Gamma$ with four rate catagories) an iterative procedure described in Swofford et al.[64] was used to converge on the best fitting model parameters. The resulting model parameters were then fixed for ML analyses and a heuristic search was performed with random taxon addition using TBR branch swapping. Two hundred bootstrap replicates [65] were performed for each data set, each replicate with a single random taxon addition and NNI branch swapping. For BI analyses (also using $\mathrm{GTR}+\mathrm{I}+\Gamma$ ) two runs each with four markov chains running five million generations were performed. The heated markov chain was sampled every $100^{\text {th }}$ generation. The -ln likelihood scores were plotted against generation number and all samples collected prior to the markov chain reaching stationarity were discarded as burn-in. The remaining samples were summarized using the sumt command in MrBayes. The insertion/deletion matrix was analyzed using the maximum parsimony (MP) criterion in PAUP* as unordered characters with 10 random taxon additions and 200 bootstrap replicates. BI analyses of amino acid data sets were executed in a fashion similar to the nucleotide analyses. We used a fixed model, cpREV $+\mathrm{I}+\Gamma$, estimated specifically for phylogenetic estimation of plastidencoded proteins [66]. ML bootstrap analyses of amino acid data were performed in RAxML also using cpREV $+\mathrm{I}+\Gamma[67]$.

\section{Additional material}

\footnotetext{
Additional file 1: Plastid tufA pseudogene in Isoetes flaccida. The tufA-like nucleotide sequence identified in the Isoetes flaccida plastome was aligned with the plastid encoded tufA sequence of Chara vulgaris using ClustalW [85]. An asterisk $\left(^{*}\right)$ indicates identical nucleotides and a dash (-) indicates insertion/deletion event (indel). A total $41 \%$ nucleotide similarity and 38 indels were identified.
} 


\begin{abstract}
Additional file 2: Angiosperm phylogenetic results using nucleotide data. The identical angiosperm topology was recovered using nucleotide data regardless of taxon set or analytical method. Nodes with bootstrap proportions (BP) $=100$ or posterior probabilities (PP) $=1.0$ are not shown (most nodes). Support was generally strong within the angiosperms with a few exceptions (shown). Nymphaea alba was always sister to remaining angiosperms, not Amborella trichopoda. Support for this was variable (BS $=78-90 \%$ depending on taxon set) and this has been addressed better elsewhere (Leebens-Mack et al.[80]). Mapped non-homoplastic indels are shown in yellow circles) and homoplastic indels are not shown.
\end{abstract}

Additional file 3: Phylogenetic results using inferred amino acid data. A) Cladogram based on ML analysis using RAxML of 49 inferred amino acid sequences from all 43 plastomes sampled (-In =

181034.78356; Table 1). RAxML and BI analyses including all taxa as well as those excluding both Selaginella spp. and gnetophytes (- $\mathrm{In}=$ 149105.09124) also converged on this topology. Numbers above the branches are ML bootstrap proportions and numbers below are Bayesian posterior probabilities in this order: all taxa included/Selaginella spp. excluded/gnetophytes excluded/Selaginella spp. and gnetophytes excluded. Support within the angiosperms was generally low in RAxML analyses. Nymphaea alba was always sister to remaining angiosperms, not Amborella trichopoda (not shown). B) and C) Phylograms based on RAxML analysis excluding either Selaginella spp. $(-\ln =163523.52584)$ or gnetophytes (-In $=166579.56793)$, respectively. In all phylogenetic analyses of inferred amino acid sequences angiosperms, gymnosperms, lycophytes, monilophytes and bryophytes (in the broad sense) were each monophyletic. However, two different best topologies were discovered depending on taxon set and analytical method. In all BI analyses regardless of taxon set as well as RAxML analyses including all taxa and excluding both Selaginella spp. and gnetophytes, the lycophytes were sister to seed plants and monilophytes were sister to all other land plants (including bryophytes) (Additional file 3A). This relationship is inconsistent with most published phylogenies including our nucleotide sequence analyses. Branching order within the monilophytes differed from the topology found using nucleotide data in that Angiopteris evecta, Equisetum arvense and Psilotum nudum formed a paraphyletic grade with respect to Adiantum capillus-veneris and Alsophila spinulosa; E. arvense was sister to the leptosporangiate ferns and Angiopteris evecta was sister to the clade containing all other monilophytes. The position of Angiopteris evecta is inconsistent with previously published phylogenies [e.g., Pryer et al.[46]]. A different topology was found in RAxML analyses that excluded either Selaginella spp. or the gnetophytes (but not both). In these analyses, monilophytes were found sister to seed plants and bryophytes were sister to all other land plants (Additional file 3B, 3C). Although Angiopteris evecta, Equisetum arvense and Psilotum nudum still formed a paraphyletic grade, the relative positions of $A$. evecta and $P$. nudum were switched. Placement of $A$. evecta, $E$. arvense and $P$. nudum had high posterior probabilities (1.0 throughout), but bootstrap support for these clades was low. All nodes within the monilophyte clade had less than 65\% support in RAxML bootstrap analyses except for the sister relationship between Adiantum capillus-veneris and Alsophila spinulosa.

Additional file 4: Insertion/deletion (indel) matrix Insertion/deletion events (indels) scored across the 49 aligned protein-coding genes used in this study. Characters were scored as 1 for presence or 0 for absence of a sequence stretch. Character state labels (CHARSTATELABELS) indicate in which gene the indel was identified and the position within that gene using the nucleotide alignment in Additional file 5.

Additional file 5: Nucleotide alignment Alignment of 49 genes from 43 plastomes used for phylogenetic analysis described in the text. Data are interleaved by gene and exclusion blocks are provided at the end of the file.

\section{Acknowledgements}

We thank Jo Ann Banks, Robert Jansen, James Leebens-Mack and Linda Raubeson for access to unpublished data. We also thank Andrew G. Murdock and Melvin J. Oliver for invaluable assistance in various aspects of this project and anonymous reviewers for helpful suggestions to improve the manuscript. This research was supported in part by the U.S. National Science Foundation grant DEB-0228660 to RGO, DEB-0228432 to PGW, DEB0228679 to KSR, DEB-0228729 to BDM and JLB and by the U.S. National Institutes of Health Interdisciplinary Training in Genomic Sciences Grant T32HG00035 to KGK. This work was also partly conducted by the U.S.

Department of Energy Joint Genome Institute supported by the Office of Science of the U.S. Department of Energy under Contract No. DE-AC0205CH11231.

\section{Author details}

${ }^{1}$ The Lewis B. and Dorothy Cullman Program for Molecular Systematics Studies, The New York Botanical Garden, Bronx, New York 10458, USA. ${ }^{2}$ Benaroya Research Institute at Virginia Mason, 1201 Ninth Avenue, Seattle, WA 98101, USA. ${ }^{3}$ Department of Energy Joint Genome Institute, 2800 Mitchell Drive, Walnut Creek, CA 94598, USA. ${ }^{4}$ Genome Project Solutions, 1024 Promenade Street, Hercules, CA 94547, USA. ${ }^{5}$ Ecology Center and Department of Biology, Utah State University, Logan, UT 84322, USA. ${ }^{6}$ Department of Biology, University of Washington, Seattle, WA 98195, USA. ${ }^{7}$ Physical Biosciences, Lawrence Berkeley National Laboratory, 1 Cyclotron Rd, Berkeley, CA. 94720 USA. ${ }^{8} 4500$ NE 40th Street, Seattle, WA 98105, USA. ${ }^{9}$ Department of Integrative Biology and University and Jepson Herbaria, 1001 Valley Life Sciences Bldg., University of California, Berkeley, CA 94720, USA.

${ }^{10}$ Southern IIlinois University, Plant Biology-SIUC, Mailcode: 6509, Carbondale, IL 62901, USA.

\section{Authors' contributions}

PGW, BDM, KSR, RGO, DFM and JLB designed the study. KA and KDEE performed the plastid isolations and flow cytometric sorting. JLB and JVK led the plastome sequencing and assembly. SKH, AMD, PGW and KGK contributed to plastome assembly, finishing and annotation. KGK and JDH performed the phylogenetic analyses and KGK, JDH, PGW and AMD performed plastome comparisons. KGK and PGW wrote a first draft, which final version was completed by KGK, PGW, KSR, JDH, RGO, BDM, KDEE and $J L B$. All authors read and approved the final manuscript.

Received: 18 February 2010 Accepted: 23 October 2010 Published: 23 October 2010

\section{References}

1. Olmstead RG, Palmer JD: Chloroplast DNA systematics-a review of methods and data analysis. Am J Bot 1994, 81:1205-1224.

2. Palmer JD, Zamir D: Chloroplast DNA evolution and phylogenetic relationships in Lycopersicon. Proc Natl Acad Sci USA 1982, 79: 5006-5010.

3. Downie SR, Palmer JD: The use of chloroplast DNA rearrangements in reconstructing plant phylogeny. In Molecular systematics of plants. Edited by: Soltis PS, Soltis DE, Doyle JJ. New York, NY: Chapman and Hall; 1992:14-35.

4. Palmer JD, Stein DB: Chloroplast DNA from the fern Osmunda cinnamomea: Physical organization, gene localization and comparison to angiosperm chloroplast DNA. Curr Genet 1982, 5:165-170.

5. Raubeson LA, Jansen RK: Chloroplast DNA evidence on the ancient evolutionary split in vascular land plants. Science 1992, 255:1697-2699.

6. Raubeson LA, Jansen RK: A rare chloroplast-DNA structural mutation is shared by all conifers. Biochem Syst Ecol 1992, 20:17-24.

7. Kelch DG, Driskell A, Mishler BD: Inferring phylogeny using genomic characters: A case study using land plant plastomes. In Molecular Systematics of Bryophytes (Monographs in Systematic Botany 98). Edited by: Goffinet B, Hollowell V, Magill R. St. Louis: Missouri Botanical Garden Press; 2006:3-12.

8. Ohyama K, Fukuzawa H, Kohchi T, Shirai H, Sano T, Sano S, Umesono K, Shiki Y, Takeuchi M, Chang Z, Aota S, Inokuchi H, Ozeki H: Chloroplast gene organization deduced from complete sequence of liverwort Marchantia polymorpha chloroplast DNA. Nature 1986, 322:572-574.

9. Shinozaki K, Ohme M, Tanaka M, Wakasugi T, Hayashida N, Matsubayashi T, Zaita N, Chunwongse J, Obokata J, Yamaguchi-Shinozaki K, Ohto C, Torazawa K, Meng BY, Sugita M, Deno H, Kamogashira T, Yamada K, Kusuda J, Takaiwa F, Kato A, Tohdoh N, Shimada H, Sugiura M: The complete nucleotide sequence of tobacco chloroplast genome: Its gene organization and expression. EMBO J 1986, 5:2043-2049. 
10. Jansen RK, Raubeson LA, Boore JL, dePamphilis CW, Chumley TW, Haberle RC, Wyman SK, Alverson AJ, Peery R, Herman SJ: Methods for obtaining and analyzing whole chloroplast genome sequences. Method Enzymol 2005, 395:348-384.

11. Pryer KM, Schneider $H$, Smith AR, Cranfill $R$, Wolf $P G$, Hunt JS, Sipes SD: Horsetails and ferns are a monophyletic group and the closest living relatives to seed plants. Nature 2001, 409:618-622.

12. Qiu YL, Li LB, Wang B, Chen ZD, Dombrovska O, Lee J, Kent L, Li RQ, Jobson RW, Hendry TA, Taylor DW, Testa CM, Ambros M: A nonflowering land plant phylogeny inferred from nucleotide sequences of seven chloroplast, mitochondrial, and nuclear genes. Int J Plt Sci 2007, 168:691-708.

13. Qiu YL, Li LB, Wang B, Chen ZD, Knoop V, Groth-Malonek M, Dombrovska O, Lee J, Kent L, Rest J, Estabrook GF, Hendry TA, Taylor DW, Testa CM, Ambros M, Crandall-Stotler B, Duff RJ, Stech M, Frey W, Quandt D, Davis CC: The deepest divergences in land plants inferred from phylogenomic evidence. Proc Natl Acad Sci USA 2006, 103:15511-15516.

14. Wikstrom N, Pryer KM: Incongruence between primary sequence data and the distribution of a mitochondrial atp 1 group II intron among ferns and horsetails. Mol Phylo Evol 2005, 36:484-493.

15. Lemieux C, Otis C, Turmel M: A clade uniting the green algae Mesostigma viride and Chlorokybus atmophyticus represents the deepest branch of the Streptophyta in chloroplast genome-based phylogenies. BMC Biol 2007, 5:2.

16. Turmel M, Pombert JÄo, Charlebois P, Otis C, Lemieux C: The green algal ancestry of land plants as revealed by the chloroplast genome. Int J P/t Sci 2007, 168:679-689.

17. Hirao T, Watanabe A, Kurita M, Kondo T, Takata K: Complete nucleotide sequence of the Cryptomeria japonica D. Don. chloroplast genome and comparative chloroplast genomics: Diversified genomic structure of coniferous species. BMC Plt Biol 2008, 8:70.

18. McCoy SR, Kuehl JV, Boore JL, Raubeson LA: The complete plastid genome sequence of Welwitschia mirabilis: An unusually compact plastome with accelerated divergence rates. BMC Evol Biol 2008, 8:130.

19. Wu CS, Lai YT, Lin CP, Wang YN, Chaw SM: Evolution of reduced and compact chloroplast genomes (cpDNAs) in gnetophytes: Selection toward a lower-cost strategy. Mol Phylo Evol 2009, 52:115-124.

20. Wu CS, Wang YN, Liu SM, Chaw SM: Chloroplast genome (cpDNA) of Cycas taitungensis and $56 \mathrm{cp}$ protein-coding genes of Gnetum parvifolium: Insights into cpDNA evolution and phylogeny of extant seed plants. Mol Biol Evol 2007, 24:1366-1379.

21. Hansen DR, Dastidar SG, Cai ZQ, Penaflor C, Kuehl JV, Boore JL, Jansen RK: Phylogenetic and evolutionary implications of complete chloroplast genome sequences of four early-diverging angiosperms: Buxus (Buxaceae), Chloranthus (Chloranthaceae), Dioscorea (Dioscoreaceae), and Illicium (Schisandraceae). Mol Phylo Evol 2007, 45:547-563.

22. Jansen RK, Cai Z, Raubeson LA, Daniell H, dePamphilis CW, Leebens-Mack J, Muller KF, Guisinger-Bellian M, Haberle RC, Hansen AK, Chumley TW, Lee SB, Peery R, McNeal JR, Kuehl JV, Boore JL: Analysis of 81 genes from 64 plastid genomes resolves relationships in angiosperms and identifies genome-scale evolutionary patterns. Proc Natl Acad Sci USA 2007, 104:19369-19374.

23. Raubeson LA, Peery R, Chumley TW, Dziubek C, Fourcade HM, Boore $J$, Jansen RK: Comparative chloroplast genomics: analyses including new sequences from the angiosperms Nuphar advena and Ranunculus macranthus. BMC Genomics 2007, 8:174.

24. Baldauf SL, Manhart JR, Palmer JD: Different fates of the chloroplast tufA gene following its transfer to the nucleus in green algae. Proc Natl Acad SCi USA 1990, 87:5317-5321.

25. Baldauf SL, Palmer JD: Evolutionary transfer of the chloroplast tufA gene to the nucleus. Nature 1990, 344:262-265.

26. Sugita M, Murayama Y, Sugiura M: Structure and differential expression of two distinct genes encoding the chloroplast elongation factor Tu in tobacco. Curr Genet 1994, 25:164-168.

27. Roper JM, Hansen SK, Wolf PG, Karol KG, Mandoli DF, Everett KDE, Kuehl J, Boore JL: The complete plastid genome sequence of Angiopteris evecta (G. Forst.) Hoffm. (Marattiaceae). Am Fern J 2007, 97:95-106.

28. Wickett NJ, Zhang Y, Hansen SK, Roper JM, Kuehl JV, Plock SA, Wolf PG, dePamphilis CW, Boore JL, Goffinet B: Functional gene losses occur with minimal size reduction in the plastid genome of the parasitic liverwort Aneura mirabilis. Mol Biol Evol 2008, 25:393-401.

29. Mindell DP, Sorenson MD, Dimcheff DE: An extra nucleotide is not translated in mitochondrial ND3 of some birds and turtles. Mol Biol Evol 1998, 15:1568-1571.

30. Kugita M, Kaneko A, Yamamoto Y, Takeya Y, Matsumoto T, Yoshinaga K: The complete nucleotide sequence of the hornwort (Anthoceros formosae) chloroplast genome: Insight into the earliest land plants. NuCl Acids Res 2003, 31:716-721.

31. Wolf PG, Rowe CA, Hasebe M: High levels of RNA editing in a vascular plant chloroplast genome: analysis of transcripts from the fern Adiantum capillus-veneris. Gene 2004, 339:89-97.

32. Oliver MJ, Murdock AG, Mishler BD, Kuehl JV, Boore JL, Mandoli DF, Everett KDE, Wolf PG, Duffy AM, Karol KG: Chloroplast genome sequence of the moss Tortula ruralis: gene content, polymorphism, and structura arrangement relative to other green plant chloroplast genomes. BMC Genomics 2010.

33. Sugiura C, Kobayashi Y, Aoki S, Sugita C, Sugita M: Complete chloroplast DNA sequence of the moss Physcomitrella patens: Evidence for the loss and relocation of rpoA from chloroplast to the nucleus. Nucl Acids Res 2003, 31:5324-5331.

34. Goffinet B, Wickett NJ, Werner O, Ros RM, Shaw AJ, Cox CJ: Distribution and phylogenetic significance of the 71-kb inversion in the plastid genome in Funariidae (Bryophyta). Ann Bot 2007, 99:747-753.

35. Tsuji S, Ueda K, Nishiyama T, Hasebe M, Yoshikawa S, Konagaya A, Nishiuchi T, Yamaguchi K: The chloroplast genome from a lycophyte (microphyllophyte), Selaginella uncinata, has a unique inversion, transpositions and many gene losses. J Plt Res 2007, 120:281-290.

36. Hasebe M, Iwatsuki K: Gene localization on the chloroplast DNA of the maiden hair fern: Adiantum capillis-veneris. Bot Mag Tokyo 1992, 105:413-419.

37. Wolf $P G$, Rowe CA, Sinclair RB, Hasebe M: Complete nucleotide sequence of the chloroplast genome from a leptosporangiate fern, Adiantum capillus-veneris L. DNA Res 2003, 10:59-65.

38. Gao L, Yi X, Yang YX, Su YJ, Wang T: Complete chloroplast genome sequence of a tree fern Alsophila spinulosa: Insights into evolutionary changes in fern chloroplast genomes. BMC Evol Biol 2009, 9:130.

39. Wolf PG, Karol KG, Mandoli DF, Kuehl J, Arumuganathan K, Ellis MW, Mishler BD, Kelch DG, Olmstead RG, Boore JL: The first complete chloroplast genome sequence of a lycophyte, Huperzia lucidula (Lycopodiaceae). Gene 2005, 350:117-128.

40. Palmer JD, Stein DB: Conservation of chloroplast genome structure among vascular plants. Curr Genet 1986, 10:823-833.

41. Goulding SE, Olmstead RG, Morden CW, Wolfe KH: Ebb and flow of the chloroplast inverted repeat. Mol Gen Genet 1996, 252:195-206.

42. Qiu YL: Phylogeny and evolution of charophytic algae and land plants. J Syst Evol 2008, 46:287-306.

43. Goremykin W, Holland B, Hirsch-Ernst Kl, Hellwig FH: Analysis of Acorus calamus chloroplast genome and its phylogenetic implications. $\mathrm{Mol} B \mathrm{BiO}$ Evol 2005, 22:1813-1822.

44. Nishiyama T, Wolf PG, Kugita M, Sinclair RB, Sugita M, Sugiura C, Wakasugi T, Yamada K, Yoshinaga K, Yamaguchi K, Ueda K, Hasebe M: Chloroplast phylogeny indicates that bryophytes are monophyletic. $\mathrm{Mol}$ Biol Evol 2004, 21:1813-1819.

45. Renzaglia KS, Garbary DJ: Motile gametes of land plants: Diversity, development, and evolution. Cr Rev Plt Sci 2001, 20:107-213.

46. Pryer KM, Schuettpelz E, Wolf PG, Schneider H, Smith AR, Cranfill R: Phylogeny and evolution of ferns (monilophytes) with a focus on the early leptosporangiate divergences. Am J Bot 2004, 91:1582-1598.

47. Schneider H, Smith AR, Pryer KM: Is morphology really at odds with molecules in estimating fern phylogeny? Syst Bot 2009, 34:455-475.

48. Mishler BD: Deep phylogenetic relationships among "plants" and their implications for classification. Taxon 2000, 49:661-683.

49. Mishler BD: The logic of the data matrix in phylogenetic analysis. In Parsimony, Phylogeny, and Genomics. Edited by: Albert VA. Oxford: Oxford University Press; 2005:57-70.

50. Mishler BD, Kelch DG: Phylogenomics and early land plant evolution. In Bryophyte Biology: Second Edition. Edited by: Shaw AJ, Goffinet B. Cambridge: Cambridge University Press; 2009:173-197.

51. Liu Q, Xue Q: Comparative studies on codon usage pattern of chloroplasts and their host nuclear genes in four plant species. J Genet 2005, 84:55-62. 
52. Wall $\mathrm{D}$, Herbeck J: Evolutionary patterns of codon usage in the chloroplast gene rbcL. J Mol Evol 2003, 56:673-688.

53. Wright F: The 'effective number of codons' used in a gene. Gene 1990, 87:23-29.

54. Wyman SK, Jansen RK, Boore JL: Automatic annotation of organellar genomes with DOGMA. Bioinformatics 2004, 20:3252-3255.

55. Lowe TM, Eddy SR: tRNAscan-SE: A program for improved detection of transfer RNA genes in genomic sequence. Nucl Acids Res 1997, 25:955-964.

56. Lohse M, Drechse O, Bock R: OrganellarGenomeDRAW (OGDRAW): A tool for the easy generation of high-quality custom graphical maps of plastid and mitochondrial genomes. Curr Genet 2007, 52:267-274.

57. Peden JF: Correspondence Analysis of Codon Usage. Nottingham: University of Nottingham; 1999 [http://codonw.sourceforge.net].

58. Maddison DR, Maddison WP: MacClade 4: Analysis of phylogeny and character evolution. Version 4.06. Sunderland, Massachusetts: Sinauer Associates, Inc; 2003.

59. Swofford DL: PAUP*: Phylogenetic Analysis Using Parsimony (*and other methods). Version 4.0b10. Sunderland, Massachusetts: Sinauer Associates, Inc; 2003.

60. Altekar G, Dwarkadas S, Huelsenbeck JP, Ronquist F: Parallel Metropolis coupled Markov chain Monte Carlo for Bayesian phylogenetic inference. Bioinformatics 2004, 20:407-415.

61. Huelsenbeck JP, Ronquist F: MRBAYES: Bayesian inference of phylogenetic trees. Bioinformatics 2001, 17:754-755.

62. Ronquist F, Huelsenbeck JP: MrBayes 3: Bayesian phylogenetic inference under mixed models. Version 3.1.2. Bioinformatics 2003, 19:1572-1574.

63. Nylander JAA: MrModeltest. Evolutionary Biology Centre, Uppsala University: Program distributed by the author; 2004.

64. Swofford DL, Olsen GJ, Waddell PJ, Hillis DM: Phylogeny reconstruction. In Molecular Systematics. 2 edition. Edited by: Hillis DM, Moritz C, Mable BK. Sunderland, Massachusetts: Sinauer Associates, Inc; 1996:407-514.

65. Felsenstein J: Confidence limits on phylogenies: An approach using the bootstrap. Evolution 1985, 39:783-791.

66. Adachi J, Waddell PJ, Martin W, Hasegawa M: Plastid genomephylogeny and a model of amino acid substitution for proteins encoded by chloroplast DNA. J Mol Evol 2000, 50:348-358.

67. Stamatakis A, Hoover P, Rougemont J: A rapid bootstrap algorithm for the RAxML web servers. Syst Biol 2008, 57:758-771.

68. Sato S, Nakamura Y, Kaneko T, Asamizu E, Tabata S: Complete structure of the chloroplast genome of Arabidopsis thaliana. DNA Res 1999, 6:283-290.

69. Ravi V, Khurana JP, Tyagi AK, Khurana P: The chloroplast genome of mulberry: Complete nucleotide sequence, gene organization and comparative analysis. Tree Genet Genomes 2007, 3:49-59.

70. Jansen RK, Kaittanis C, Saski C, Lee SB, Tomkins J, Alverson AJ, Daniell H: Phylogenetic analyses of Vitis (Vitaceae) based on complete chloroplast genome sequences: Effects of taxon sampling and phylogenetic methods on resolving relationships among rosids. BMC Evol Biol 2006, 6:32.

71. Timme RE, Kuehl JV, Boore JL, Jansen RK: A comparative analysis of the Lactuca and Helianthus (Asteraceae) plastid genomes: Identification of divergent regions and categorization of shared repeats. Am J Bot 2007, 94:302-312.

72. Schmitz-Linneweber C, Maier RM, Alcaraz JP, Cottet A, Herrmann RG, Mache R: The plastid chromosome of spinach (Spinacia oleracea): Complete nucleotide sequence and gene organization. Plt Mol Biol 2001, 45:307-315.

73. Saski C, Lee SB, Fjellheim S, Guda C, Jansen RK, Luo H, Tomkins J, Rognli OA, Daniell H, Clarke JL: Complete chloroplast genome sequences of Hordeum vulgare, Sorghum bicolor and Agrostis stolonifera, and comparative analyses with other grass genomes. Theor Appl Genet 2007, 115:571-590.

74. Mardanov AV, Ravin NV, Kuznetsov BB, Samigullin TH, Antonov AS, Kolganova TV, Skyabin KG: Complete sequence of the duckweed (Lemna minor) chloroplast genome: Structural organization and phylogenetic relationships to other angiosperms. J Mol Evol 2008, 66:555-564.

75. Chang CC, Lin HC, Lin IP, Chow TY, Chen HH, Chen WH, Cheng CH, Lin CY, Liu SM, Chaw SM: The chloroplast genome of Phalaenopsis aphrodite (Orchidaceae): Comparative analysis of evolutionary rate with that of grasses and its phylogenetic implications. Mol Biol Evol 2006, 23: 279-291.
76. Cai ZQ, Penaflor C, Kuehl JV, Leebens-Mack J, Carlson JE, dePamphilis CW, Boore JL, Jansen RK: Complete plastid genome sequences of Drimys, Liriodendron, and Piper: implications for the phylogenetic relationships of magnoliids. BMC Evol Biol 2006, 6:77.

77. Goremykin W, Hirsch-Ernst KI, Wolfl S, Hellwig FH: The chloroplast genome of Nymphaea alba: Whole-genome analyses and the problem of identifying the most basal angiosperm. Mol Biol Evol 2004, 21:1445-1454

78. Goremykin W, Hirsch-Ernst Kl, Wolfl S, Hellwig FH: Analysis of the Amborella trichopoda chloroplast genome sequence suggests that Amborella is not a basal angiosperm. Mol Biol Evol 2003, 20:1499-1505.

79. Wakasugi T, Tsudzuki J, Ito S, Nakashima K, Tsudzuki T, Sugiura M: Loss of all ndh genes as determined by sequencing the entire chloroplast genome of the black pine Pinus thunbergii. Proc Natl Acad Sci USA 1994, 91:9794-9798

80. Leebens-Mack J, Raubeson LA, Cui LY, Kuehl JV, Fourcade MH, Chumley TW, Boore $\mathrm{JL}$, Jansen RK, dePamphilis CW: Identifying the basal angiosperm node in chloroplast genome phylogenies: Sampling one's way out of the Felsenstein zone. Mol Biol Evol 2005, 22:1948-1963.

81. Turmel M, Otis C, Lemieux C: The complete chloroplast DNA sequences of the charophycean green algae Staurastrum and Zygnema reveal that the chloroplast genome underwent extensive changes during the evolution of the Zygnematales. BMC Biol 2005, 3:22.

82. Turmel M, Otis C, Lemieux C: The chloroplast and mitochondrial genome sequences of the charophyte Chaetosphaeridium globosum: Insights into the timing of the events that restructured organelle DNAs within the green algal lineage that led to land plants. Proc Natl Acad Sci USA 2002, 99:11275-11280.

83. Turmel M, Otis C, Lemieux C: The chloroplast genome sequence of Chara vulgaris sheds new light into the closest green algal relatives of land plants. Mol Biol Evol 2006, 23:1324-1338.

84. Lemieux C, Otis C, Turmel M: Ancestral chloroplast genome in Mesostigma viride reveals an early branch of green plant evolution. Nature 2000, 403:649-652.

85. Larkin MA, Blackshields G, Brown NP, Chenna R, McGettigan PA, McWilliam H, Valentin F, Wallace IM, Wilm A, Lopez R, Thompson JD, Gibson TJ, Higgins DG: Clustal W and Clustal X version 2.0. Bioinformatics 2007, 23:2947-2948.

doi:10.1186/1471-2148-10-321

Cite this article as: Karol et al:: Complete plastome sequences of Equisetum arvense and Isoetes flaccida: implications for phylogeny and plastid genome evolution of early land plant lineages. BMC Evolutionary Biology 2010 10:321.

\section{Submit your next manuscript to BioMed Central and take full advantage of:}

- Convenient online submission

- Thorough peer review

- No space constraints or color figure charges

- Immediate publication on acceptance

- Inclusion in PubMed, CAS, Scopus and Google Scholar

- Research which is freely available for redistribution 